\title{
IMPORTANCE OF FEATURES OF DIDACTIC SOFTWARE IN THE OPINION OF TEACHERS
}

\author{
Waldemar LIB, University of Rzeszow, Poland
}

Received: 27. 7. 2017 / Accepted: 11. 11. 2017

Type of article: original research

DOI: $10.5507 /$ jtie.2017.027

Abstract: Multimedia didactic software is increasingly being used in the teaching process at all education levels. It seems that to be effective it must meet criteria that can guarantee their didactic effectiveness. Among the criteria, author counted six areas: substantive correctness, ergonomics, stimulation of interest, the possibility of smooth running of the didactic process, self-learning with the use of didactic programs and possibility of simulations of phenomena and processes. The article contains information about the results of pilot studies aimed at determining which of the above characteristics are the most important opinion of teachers of vocational subjects. As a result of the research, hierarchically determined, which of the characteristics of the book in the teacher's opinion are most important and less important.

Keywords: multimedia, multimedia didactic software, didactic.

\section{WAŻNOŚĆ CECH OPROGRAMOWANIA DYDAKTYCZNEGO W OPINII NAUCZYCIELI}

Abstrakt: Multimedialne oprogramowanie dydaktyczne coraz częściej jest stosowane $w$ procesie dydaktycznym na wszystkich poziomach edukacyjnych. Wydaje się, że aby byto skuteczne musi spetniać kryteria, które moga gwarantować ich skuteczność dydaktyczną. Do kryteriów tych autor zaliczyt sześć obszarów: poprawność merytoryczna, ergonomiczność, rozbudzanie zainteresowań przedmiotem, możliwość sprawnego przebiegu procesu dydaktycznego, samokształcenie z wykorzystaniem programów dydaktycznych oraz możliwość przeprowadzenia symulacji zjawisk i procesów. W artykule przedstawione sa wyniki badań pilotażowych mających na celu określenie, które $z$ wymienionych cech sq najważniejsze zdaniem nauczycieli przedmiotów zawodowych. $W$ wyniku przeprowadzonych badań określono hierarchicznie, które z cech podręczników sa zdaniem nauczycieli najważniejsze, a które mniej ważne.

Słowa kluczowe: multimedia, multimedialne programy dydaktyczne, dydaktyka.

* Author for correspondence: libw@univ.rzeszow.pl 


\section{Introduction}

The media are now seen as a major factor leading to the formation of a global information society, and a characteristic feature of human beings should be the ability to select and process information. The lack of such skills is contemporary illiteracy (Walat 2007: 65).

An extremely important and yet distinctive feature of didactic work in the form of multimedia didactic software is the individualization of reception, which is accompanied by an increase in the ability to establish contact with the sender. There are also greater opportunities for creative processing of information by the recipient in processing finished texts, but also creating new ones by using, among other things, animations, graphics and video sequences. A separate, broad but significant, aspect influencing the improvement of the information received is the reception of hypermedia by its interactive nature, which, by interacting with the recipient, often makes the message more effective by expressing the same terms with the help of different codes (Walat 2007: 65).

The pilot studies aim to characterize multimedia didactic programs, to determine which of them are more or less important in the view of vocational classes teachers. They will also enable the didactic process to run more effectively and efficiently. The above mentioned characteristics of didactic multimedia programs have been pinpointed to the creators. Further research can lead to enhance the theory of multimedia didactic programs and e-textbooks.

\section{Multimedia in education}

Multimedia-based learning is characterized by the fact that it is multi-faceted learning, interacting with many senses at the same time as well as multilaterally activating the learner. Humans learn not only using a system of verbal signs, but also graphical, pictorial and audial signs.

In the literature,we can find many educational areas in which multimedia is used, including:

1. Teaching process:

a) developing school curricula - creating databases, developing goals and analyzing collected materials,

b) support for education - cooperation with programs supporting the teachinglearning processes, presentation of didactic materials, use of expert systems, e.g. use of various tests to check the level of knowledge and skills acquired, use of multimedia to develop creative abilities, development of various abilities through educational games, computer simulations that allow participation in real processes that are inaccessible to the student,

c) didactic monitoring supporting the work of the teacher - using multimedia to develop information in databases, spreadsheets and other programs to improve the work of the teacher and the school.

2. Diagnostics and pedagogical therapy:

a) tools especially useful for working with people with disabilities,

b) the possibility of pedagogical diagnosis,

c) the possibility to conduct pedagogical therapy.

3. Organization and management of educational institutions:

a) management in a wide form, including administration of school work, 
b) planning the educational process,

c) the possibility of creating a process for improving teaching staff skills in pedagogical and substantive preparation.

4. Pedagogical research:

a) supporting assessment of the quality of education and the education system,

b) enabling analysis of the functioning of the school (cf. Kandzia 2011: 19-21).

\section{Multimedia teaching programs in the teaching-learning process}

For many years such authors as Juszczyk (1997: 17), Sysło (2002: 172), Walat (2007: 97-125), Lib (2012: 5), Ciesielka: (2013), Myers, Halpin (2002: 133-140), Ashvini (2012: 33-36) and othershave emphasized that a program that is well-developed in terms of content and didactics has the potential to increase the assimilation of presented content by a multi-sensory impact on the learning brain. This influence can be expressed asinfluencing the learners' brains by:

- visual field-graphics, color scheme,

- hearing perception- sound, music,

- movement perception - tracking of movements visible on a monitor, animation, film,

- $\quad$ speech field -communication by messaging,

- $\quad$ somatic perception - carrying out instructions, exercises, simulations, etc. (see Gajda 2010: 21).

The concept of multimedia education is preferred by a large number of educators. It is also reflected in the core curriculum of general education for primary and secondary and upper secondary schools. In each case, there are numerous advantages to using multimedia.

With reference to Rogulska's innovative teaching aids (2012: 25-26), the following features of multimedia education are mentioned:

- it causes a change in the very important aspect of psychodydactic learning, because often the level of motivation of the learner is changed, for which the use of multimedia is very attractive during school activities where there are other forms of communication besides speaking and reading,

- $\quad$ such a form of teaching requires modification of the way teachers work - it often requires more involvement, use ofimagination, a creative approach; there is the possibility of common (teacher with student) creation of teaching materials,

- didactic programs provide the opportunity to individualize education (by selecting the educational pathway that the student follows in the program itself and by the pace of work, the choice of media presentations- text, teacher'svoice, animation, film, simulation, etc.), which may positively affect the uptake of knowledge.

A didactic program is any scientific study that addresses specific problems in the pedagogical activity of teachers. Its main purpose is to define the method and form of application of pedagogical factors in order to optimize pedagogical activities in order to optimize activities in view of the adopted objectives. These programs are essentially a subsystem of the education system of a given field of education (Walat 2007: 57).

Apart from the pedagogical aspects of multimedia didactic programs, they contain two important groups: 
- $\quad$ substantive - correctness of the content of the presented information,

- ergonomic - technical solutions adopted in the program, including text clarity, presentation format, color scheme, layout and size of the interface, program color scheme, font selection and size, screen layout, ease of use, intuitiveness of operation,

\section{Tools and research methods}

Taking into account the aforementioned features of didactic software, the following categories of features were considered in the study:

- $\quad$ substantive merits, including related communication competencies (Q1, Q3, Q11, Q16, Q21, Q29, Q37, Q48, Q55, Q59)

- $\quad$ ergonomic (features described in questions Q2, Q4, Q10, Q12, Q22, Q30, Q38, Q47, Q49, Q57)

- $\quad$ stimulating interest in the subject matter (features described in questions Q5, Q17, Q20, Q23, Q28, Q31, Q36, Q46, Q50, Q54)

- possibility of efficient flow of the didactic process (features described in questions Q6, Q15, Q18, Q27, Q32, Q34, Q41, Q42, Q45, Q58)

- $\quad$ self-study with the use of didactic software (features described in questions Q7, Q8, Q14, Q24, Q26, Q33, Q39, Q43, Q51, Q53)

- $\quad$ possibility of simulating phenomena and processes (features marked with Q9, Q13, Q19, Q25, Q35, Q40, Q44, Q52, Q56, Q60).

Each of these categories is describedby ten specific characteristics that formed the basis for constructing the Q-test in which the surveyed teachers indicated what they thought were the most important and those that were least important.

The Q-test is a statistical research tool consisting of a set of 60 featuresarranged at random. It contains instructions for answering. The teachers were asked a general question: which of the following characteristics they think are the greatest and which are the least important for didactic software.

The scale used in the test is between 0 and 10, with 0 being the least significant, and 10 the highest. The features identified by the number 5 are neutral. In the test participants can choose 2, 3, 4, 7, 9 attributes of the smallest and the biggest and 10 neutral ones.

The researchwas carried out using an electronic version of the test and the testing itself was conducted using the Internet.

Teachers working in basic vocational schools, technical schools and Vocational Training Centers located in the city of Rzeszów were involved in the research; they were teachersofboth theoretical and practical subjects. These teachers used multimedia teaching software to present information, develop specific skills, and simulate industrial phenomena and processes. A large number also used control blocks included in the program for verifying the level of assimilated knowledge as well as simulation tests to determine how a student behaves in a particular professional situation. 


\section{Characteristics of the study group}

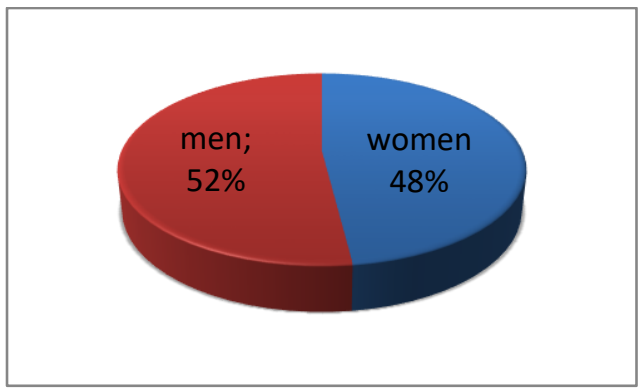

Chart 1: Characteristics of respondents on the basis of: gender.

Source: Own elaboration

Teachers working in vocational education took part in the study. In the overall group of teachers, a small majority were male, $52 \%$ of the respondents.

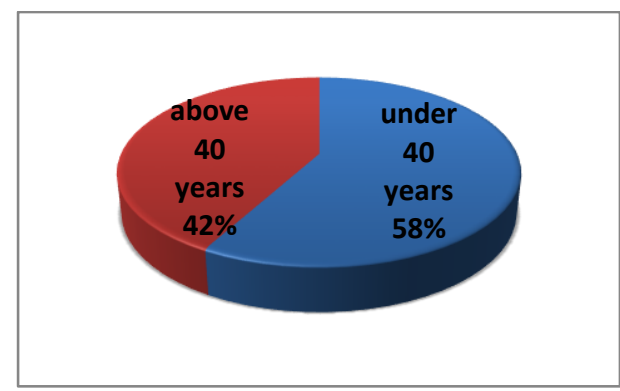

Figure 2: Characteristics of the respondents by age. Source: Own elaboration

Most of the teachers were young, $58 \%$ under 40 years old, which seems to have been beneficial for the research.

From the observations of the people who took part in the study, it was noted that the younger teachers were more likely and willing (16\%) to fill in the test presented electronically than the older teachers. This may be due to the fact that it is this group that more often and more willingly uses computers and computer software in their work, and also used computers while studying at university, so their fears are smaller and their readiness to use such a form of work is greater. 


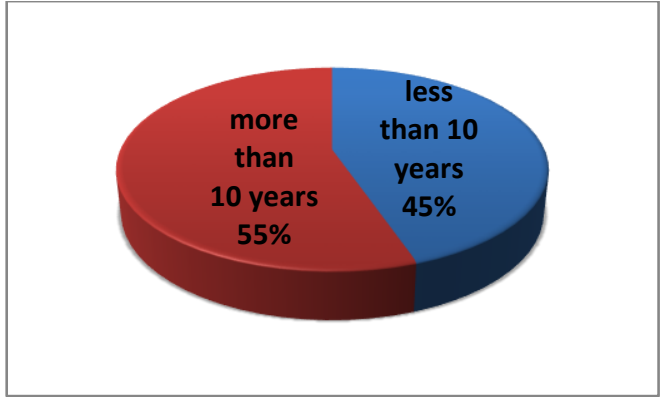

Figure 3: Characteristics of the respondents on the basis of work experience.

Source: Own elaboration

As far as work experience is concerned, there were $15 \%$ more teachers who had been working in education for more than 10 years than teachers working less than 10 years. So they were young teachers with more than 10 years of work experience. This leads to an important conclusion that further research needs to be scaled up, as they probably were teachers with a little over 10 years of work but no more than 15 years.

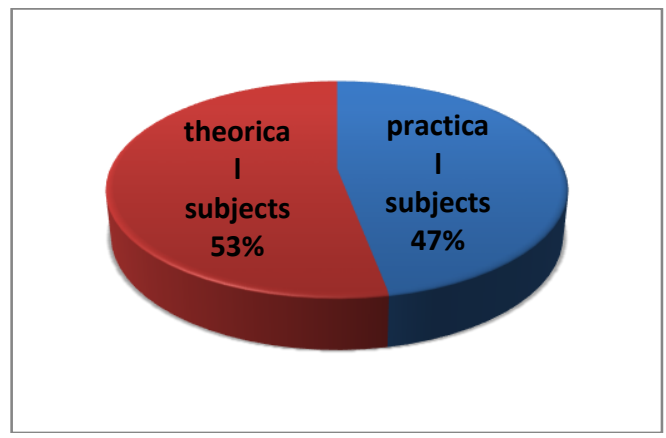

Figure 4: The use of didactic programs for theoretical and practical subjects. Source: Own elaboration

Among those surveyed 53\% were teachers of theoretical subjects, for which multimedia teaching programs are primarily used as teaching aids to convey information in the form of text, commentary, animations, films, and control blocks with less frequent simulation of phenomena and processes. Programs that simulate phenomena and processes are most often used by practical vocational teachers. These simulations may involve measurements, breakdowns, design ofproduction or operation of equipment. The group of practical vocational teachers is $47 \%$ of all respondents. 


\section{Analysis of research results}

Key features of didactic software with respect to the gender of the surveyed teachers

Q12 - information presented in a...

Q6 - student time discipline during...

Q20 - presenting information in a...

Q18 - tasks that develop practical skills

Q3 - recognition of knowledge...

Q5 - introduction of exercises in less...

Q9 - innovative forms of activity make...

Q4 - knowledge transmitted through...

Q1 - showing the practical usefulness...

Q2 - presentation of issues using...

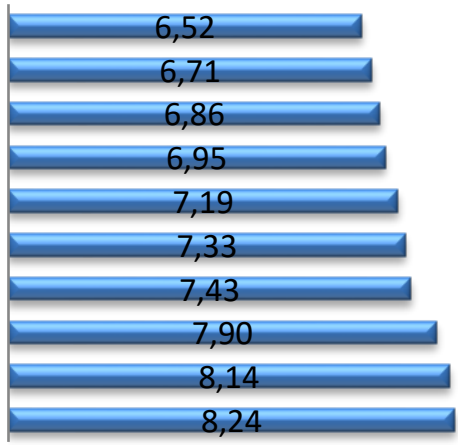

Figure 5: The most important features of didactic software in the opinion of men Source: Own elaboration

In the above figure5, it can be seen that the most important qualities for the men surveyed included those associated with the ergonomics of the didactic software $(\mathrm{Q} 2$ and Q4) and related to the substantive merits of the teaching content (Q1 and Q3). Among the ten most important features identified by male teachers are also those that are related to interest-raising concerns (Q5 and Q23). Males also considered as important the factors that influence the efficiency of the didactic process (Q18 and Q6).

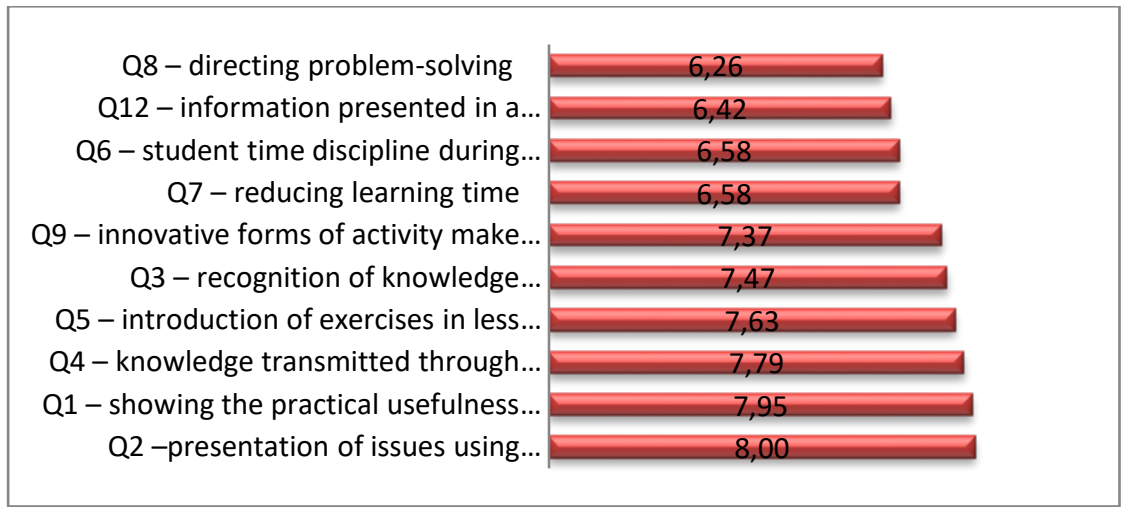

Figure 6: The most important features of didactic software in the opinion of women Source: Own elaboration 
In Figure 6, the most important qualities of women teachers are the ergonomics of the teaching software (Q2, Q4 and Q12). Here, however, it may be noted that women even more strongly than men consider them important, because apart from the Q2 and Q4 qualities, Q12 also qualifies as important. As can be seen in the description they are related to the form of transmission of information: Q2 - presentation of issues using modern visualizationtechniques, Q4 -knowledge transmitted through various forms, not only by text but also illustrations, Q12 -information presented in a variety of forms.

Other qualities are related to substantive merits (Q1 and Q3) and these are exactly the same qualities that men consider important and also in similar order. Among the 10 most important qualities recognized by women are also those related to self-study (Q7 and Q8). Here the men considered the "more interesting subjects" and the "didactic process" more important categories.

It is interesting that teachers consider the essential features of teaching software to be related to the ergonomics of the software, and particularly to the form of the transmission of information, and the substantive merits are pushedinto the background.

\section{Key features of didactic software with respect to teachers' age}

The research shows that teachers up to the age of 40 (Figure 6) consider the most important features of didactic software to be those related to software ergonomics, and there are as many as 3 of them: presentation of issues using modern visualization techniques; knowledge transmitted through a variety of forms, not only through text but also illustration; and the interactive nature of hypermedia. Teachers up to the age of 40 also included those that are related to substantive merits, i.e. showing the practical relevancy of the familiarised issues and presenting knowledge with the logic of the given discipline of knowledge.

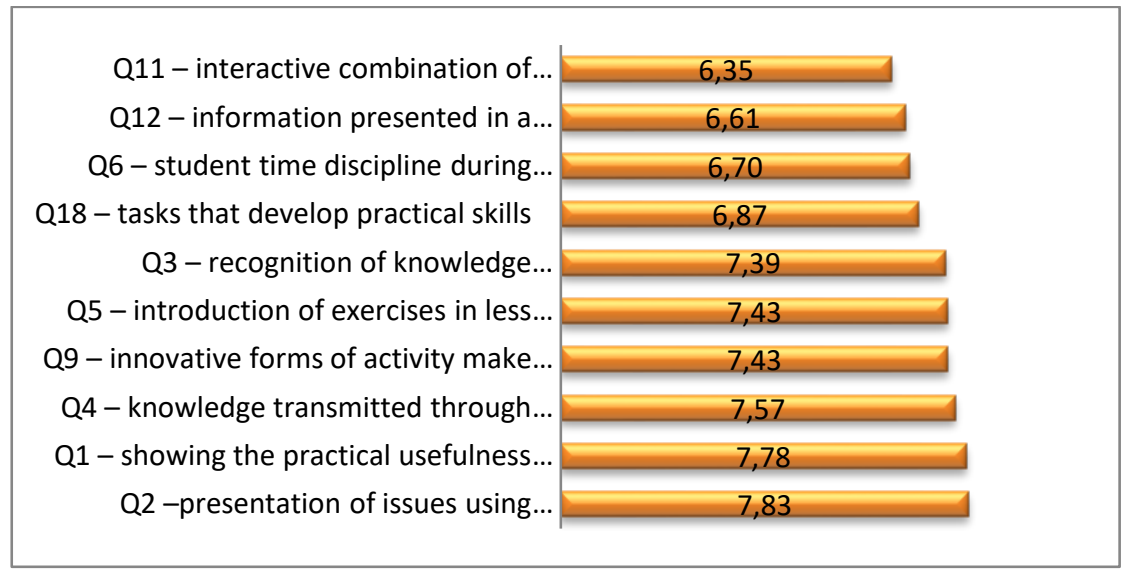

Figure 7: The most important features of didactic software in the opinion of teachers up to 40 years old (source: own elaboration) 
In Figure 8, it can be seen that among teachers over the age of 40 there is a resemblance to the most important features of teaching software for teachers up to the age of 40 years. These teachers also recognized the same characteristics resulting from ergonomics and substantive merits. The characteristics indicated as the 10 most important forboth the younger and the older were marked as Q2, Q1, Q4, Q5, Q9, Q3 and Q6. In addition, younger people also pointed to: Q18 - tasks that develop practical skills, Q12 -information presented in a variety of forms and Q11 - interactive combination of related content. Older people also indicated features marked Q20 -presenting information in a simple, clear and understandable way. Q8 - directing problem-solving and Q7 -reducing learning time.

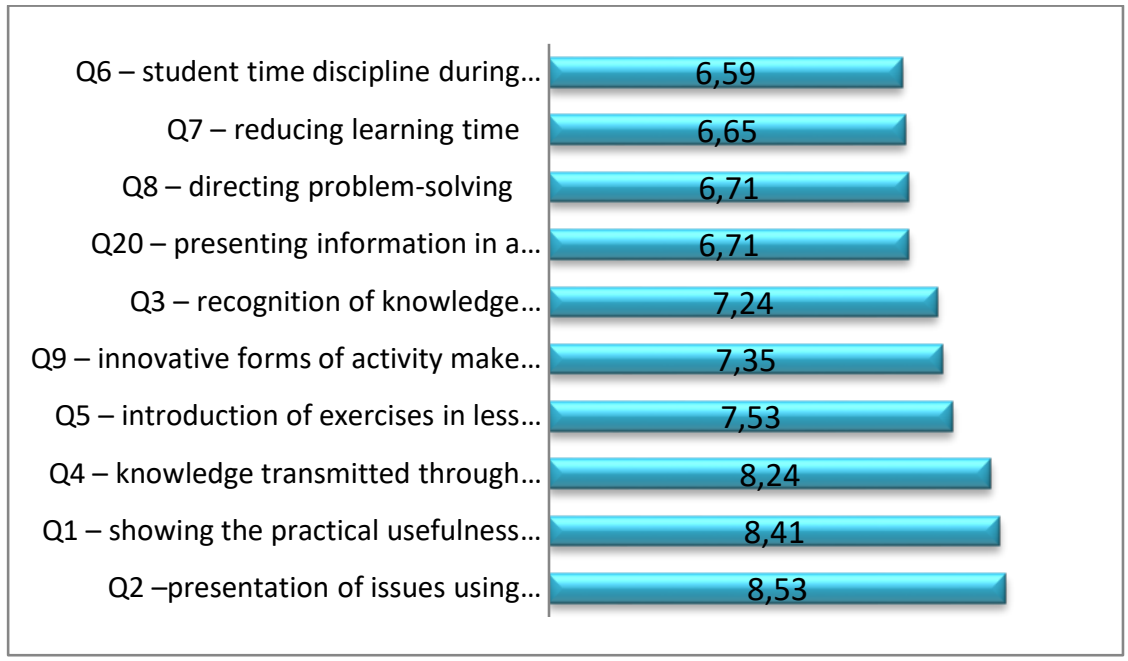

Figure 8: The most important features of didactic software in the opinion of teachers over 40 years old

Source: Own elaboration

Figure 8 shows the results of the 10 most important features of teaching software in the opinion of teachers over 40 years of age. It can be seen that the teachers, like their younger colleagues, recognized the features of software ergonomics and substantive merits as the most important ones. The attributes indicated in the top ten are the attributes Q2, Q1, Q4, Q5, Q9, Q3, and Q6. In addition, the younger teachers also indicated the following characteristics: Q18, Q12 and Q11, and the older teachers indicated the features marked Q20, Q8 and 


\section{Key features of didactic software with respect to teachers' work experience}

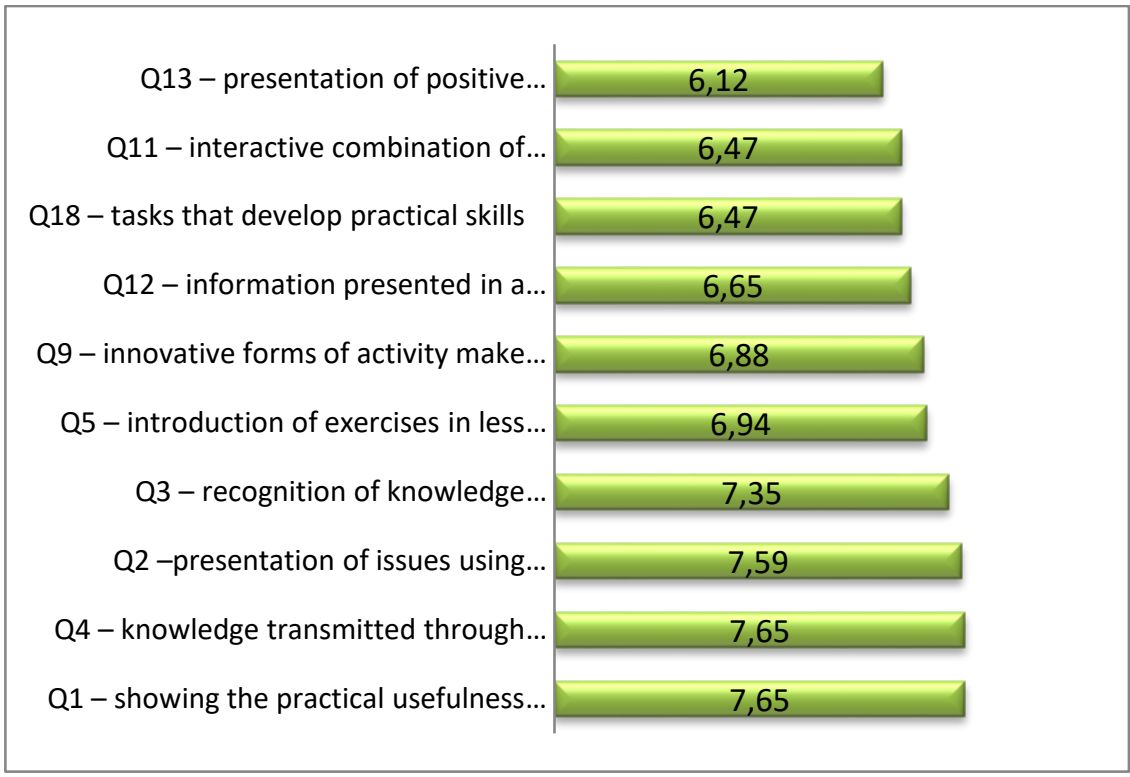

Figure 9: The most important features of didactic software in the opinion of teachers working less than 10 years Source: Own elaboration

Among teachers with less than 10 years'work experience, there is a conviction that the most important feature of teaching software is the Q1 feature - "showing the practical usefulness of the familiarised issues". Features of "substantive merits " and "ergonomic" multimedia teaching programs have an advantage over the features of the other categories. They also pointed out two features in the category of "simulating phenomenaandprocesses" and one of the categories "the ability to perform didactic processes efficiently" and "stimulating an interest in the subject".

Figure 10, below, graphically illustrates the results of the research on the 10 most important features of didactic software in the opinion of teachers working over 10 years. It follows that teachers with longer work experience consider the characteristics associated with ergonomics and substantive merit. Feature Q2 -presentation of issues using modern visualization techniques, was considered the most important. The respondents also believe that the most important qualities are those related to self-study, which include Q8 and Q7, as well as the ability to perform the didactic process, i.e. Q6 and Q18.

The qualities that were assigned to the top 10 as indicated by the two groups of teachers are Q1, Q4, Q5, Q9 and Q18. People working for a shorter time also pointed to Q3, Q12, Q11 and Q13 features, while longer-term workers also indicated features marked Q3, Q6, Q7, and Q8. 


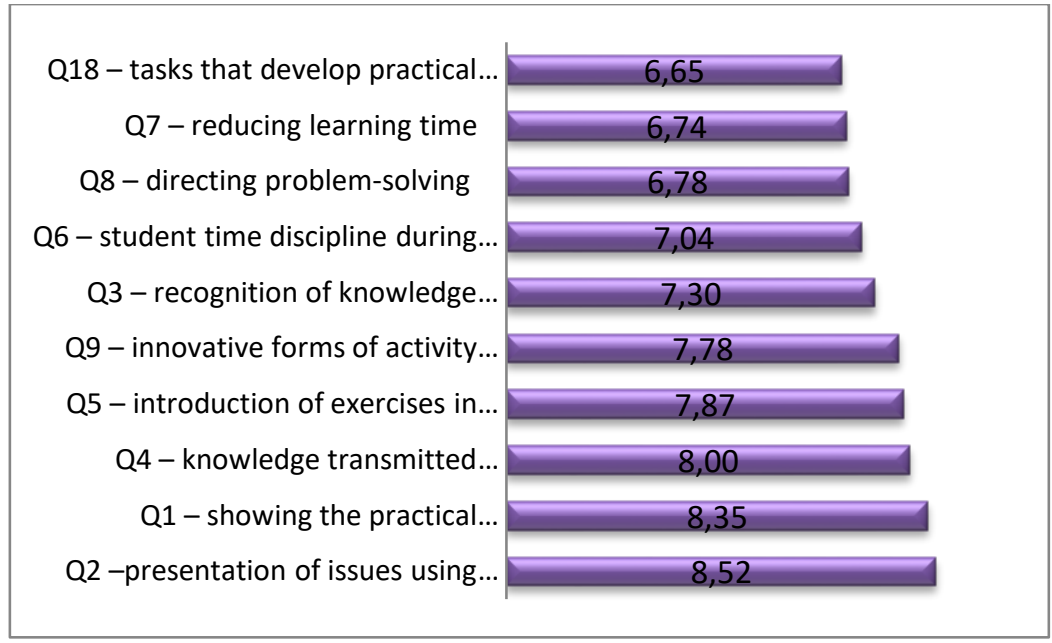

Figure10: The most important features of didactic software in the opinion of teachers working over 10 years

Source: Own elaboration

The research shows that teachers with longer working experience recognize the features of software ergonomics as well as those related to the correctness of the content. Feature Q2 - presentation of issues using modern visualization techniques, was identified as the most important by teachers with work experience of more than 10 years. Respondents believe that the most important features of didactic software include features ofthe category "self-study with the use of didactic software", and these are marked as Q8 and Q7, and from the category of " possibility of efficient flow of the didactic process", and these are features Q6 and Q18.

\section{Summary}

In summarizing the above considerations, the general results on the importance of individual categories and the individual characteristics of multimedia didactic software will be presented and discussed below.

\begin{tabular}{|l|c|c|}
\hline $\begin{array}{l}\text { Categories of didactic } \\
\text { features }\end{array}$ & $\begin{array}{l}\text { Determination of the } \\
\text { main characteristic }\end{array}$ & $\begin{array}{l}\text { Average Q-test indicator } \\
\text { of the given feature }\end{array}$ \\
\hline Ergonomic & B & 5,24 \\
\hline $\begin{array}{l}\text { Self-study with the use of } \\
\text { didactic software }\end{array}$ & E & 5,17 \\
\hline Substantive merits & A & 5,12 \\
\hline Interesting subject matter & C & 5,05 \\
\hline
\end{tabular}




\begin{tabular}{|l|c|c|}
\hline $\begin{array}{l}\text { Possibility of efficient flow } \\
\text { of the didactic process }\end{array}$ & D & 4,94 \\
\hline $\begin{array}{l}\text { Possibility of simulating } \\
\text { phenomena and processes }\end{array}$ & F & 4,83 \\
\hline
\end{tabular}

Table 1: The most important and least important categories of features of multimedia didactic software (source: own elaboration)

The results shown in Table 1 show that the most important qualities were those that were related to the ergonomics of the didactic programs (B), followed by self-study (E), and only in third place to the correctness of the content (A). Since substantive merits is in the middle of the hierarchy of qualities, it can be said that the substantive significance of the didactic programs is of medium importance. Another surprising result is that features related to the possibility of simulating phenomena and processes $(\mathrm{F})$ in turn are, according to vocational teachers, the least important feature group. It would seem that substantive merits is the most important feature of all for all types of education. On the other hand, in vocational training, it is also important to be able to simulate phenomena and processesthat students can meet in real-life situations and which, due to different conditions (e.g.degree of complexity and price of equipment, scale or process hazards) they cannot carry out on real systems. The ability to perform simulations is also one of the characteristics of the didactic programs, which significantly differentiates them from traditional didactic means based on written or visual text, and is also a more advanced form of knowledge transfer than animation or film. In addition, if we can say that learners, apart from knowledge, acquire skills through the use of didactic programs, they acquire them mainly by running simulations, such as device diagnosis, mechanism assembly, chemical process, heat treatment and so on.

\begin{tabular}{|l|c|c|}
\hline Categories of didactic features & $\begin{array}{l}\text { Determination of } \\
\text { the main } \\
\text { characteristic }\end{array}$ & $\begin{array}{l}\text { Average Q-test } \\
\text { indicator of the } \\
\text { given feature }\end{array}$ \\
\hline $\begin{array}{l}\text { Presentation of issues using modern } \\
\text { visualization techniques }\end{array}$ & B & 8,13 \\
\hline $\begin{array}{l}\text { Show the practical usefulness of the } \\
\text { issues shown }\end{array}$ & A & 8,05 \\
\hline $\begin{array}{l}\text { Innovative form of classes makes the } \\
\text { students more eager to participate in } \\
\text { the classes }\end{array}$ & C & 7,48 \\
\hline $\begin{array}{l}\text { Introduction of exercises in less } \\
\text { standardized form, such as simulations } \\
\text { of real activities and actions }\end{array}$ & F & 7,40 \\
\hline $\begin{array}{l}\text { Student time discipline during solving } \\
\text { of tasks }\end{array}$ & D & 6,65 \\
\hline $\begin{array}{l}\text { By using the software we shorten the } \\
\text { learning time }\end{array}$ & E & 6,42 \\
\hline
\end{tabular}

Table 2: Key features in a given category (source: own elaboration) 
In the case of the analysis of the significance of specific features, the most important opinion of the respondents was the presentation ofissues using modern visualization techniques. This feature belongs to the category of features resulting from software ergonomics (B). In second place, one item higher than in the category of features, there is a specific feature related to the correctness of the content (A). It follows that, although this particular feature is important in the opinion of the respondents, the other characteristics related to substantive merits were considerably lower. In third place, we see a feature related to developing interest inthe subject $(\mathrm{C})$, while the lowest is a feature resulting from the ability to self-study using didactic software $(\mathrm{E})$, although in the case of feature categories this feature took second place before the correctness of the content. This means that while this particular feature was considered by teachers to be of little importance, the other members of this category rated very high.

Teachers do not think that the most important features of didactic software, which like school textbooks and other teaching materials are teaching tools, is the aim to impart certain and flawless knowledge. Knowledge, in addition to developing substantive content, shapes the professional language of students and their communication skills by developing the vocabulary that belongs to a particular field in the learning lexical resource, but also develops understanding of the vocabulary and skillful use of it. Professional use of vocabulary on the one hand involves decoding of information, e.g. in instructions: for service, for current and periodic maintenance, equipment repairs, occupational health and safety, etc. It also involves encoding information by building and communicating messages to other people associated with a specific profession, such as the transmission of certain and faultless information on breakdowns, ordering of parts, performance of duties, etc. (Lib 2013: 179-191, Lib 2014: 69-80)

As mentioned above, a didactic program is any scientific study constituting a subsystem of the didactic system of a given field of education. And from this point of view it should present the correct scientific knowledge of the subject matter of teaching. Most important is the ergonomics of the program, which included the following features:

- $\quad$ presentation of issues using modern visualization techniques,

- use of only color illustrations,

- $\quad$ application of correct elements of computer typography that positively affect the student's eyesight,

- $\quad$ layout of the screen that is organized and easy to use,

- work environmentbased on colors that do not excite emotions,

- presentation of information in a variety of forms,

- $\quad$ adaption of the presentation to the student's perceptual abilities,

- the interactive nature of hypermedia,

- $\quad$ editing of messages -communications,

- messages transmitted through a variety of forms, not only using text, but also illustrations.

As can be seen, teachers place a lot of emphasis on the form of transferring information, not necessarily on the content itself and its correctness.

The results of these studies are consistent with research conducted by W. Walat [2010: 155-157] on the relevance of the characteristics of traditional school textbooks. There, the 
teachers who took part in the research also recognized the qualities that reinforced the informative function of the school book, so they focused on the form of the message and elements such as infographics, coloring, typographic layout of the pages, transferring the substantive merits of the contentpresented to the background.

The results of this comparative research might prove to be crucial for those involved in the design and the implementation of theoretical and practical issues and for the multimedia methodological guides used in schools and extracurricular education processes. It has to be pointed out that the obtained results may seem to be an important guideline for methodologists who take part in teacher-training processes. The teachers should be made aware of the validity correctness of the conducted lessons as well as the accuracy of the used guidebooks; i.e., multimedia didactic programmes and computer textbooks.

\section{Bibliography}

Ashvini J. (2012). Multimedia: A Technique in Teaching Process in the Classrooms. Current World Environment, Vol. 7(1), Nilofar Iqbal, pages 33-36, ISSN: 0973-4929.

Ciesielka M. (2013).Ocena umiejętności studentów wyższej uczelni technicznej w zakresie tworzenia prezentacji multimedialnych, [w:] Edukacja - Technika - Informatyka: wybrane problemy edukacji informatycznej i informacyjnej, nr 4 cz. 2, W. Walat, W. Lib, Wyd. UR, Rzeszów, s. 214-219.

Gajda J. (2010).Media w edukacji, Impuls, Kraków.

Juszczyk S. (1997). Interakcja człowieka z mediami [w:] Nauczyciel i szkoła 1997, nr 1(2).

Kandzia J. (2011). Kształtowanie wartości dydaktycznych $i$ wychowawczych $w$ procesie edukacji matematycznej z wykorzystaniem technik multimedialnych, Impuls, Kraków.

Lib W. (2012).Narzędzia i techniki informatyczne $w$ procesie dydaktycznym, Mitel, Rzeszów.

Lib W. (2014).Kompetencje komunikacyjne uczniów kończacych szkołe podstawowa w zakresie pojęć informatycznych - wyniki badań własnych, [w:] Edukacja Technika Informatyka: wybrane problemy edukacji informatycznej i informacyjnej, nr 4 cz. 2, W. Walat, W. Lib, Wyd. UR, Rzeszów, s. 179-191

Lib W. (2014).Kompetencje komunikacyjne uczniów kończacych szkołe podstawowa w zakresie pojęć technicznych, [w:] Edukacja Technika Informatyka: wybrane problemy edukacji technicznej i zawodowej, nr 5 cz. 1, W. Walat, W. Lib, Wyd. UR, Rzeszów, s. 69-80

Myers J., M., Halpin R. (2002). Teachers'Attitudes and Use of Multimedia Technology in the Classroom. Journal of Computing in Teacher Education, Volume 18, 2002 - Issue 4, ISTE Routledge Taylor \&Francis Group, pages: 133-140

Rogulska A. (2012). Media globalne - media lokalne. Zagadnienie z obszaru pedagogiki medialnej i edukacji regionalnej, Impuls, Kraków.

Sysło M. (2002).Multimedia w edukacji, [w:] Media a edukacja w obrębie integracji, Poznań.

Walat W. (2007). Edukacyjne zastosowanie hipermediów, Wyd. UR, Rzeszów.

Walat W. (2010).Badanie ważności funkcji podręczników do techniki $w$ opiniach nauczycieli szkót podstawowych, „Prace naukowe Akademii im. Jana Długosza w Częstochowie”, seria „Edukacja Techniczna i Informatyczna” t. V. 